\title{
Article \\ Cadmium Uptake and Growth Responses of Seven Urban Flowering Plants: Hyperaccumulator or Bioindicator?
}

\author{
Zhouli Liu ${ }^{1}$, Mengdi Chen ${ }^{2}$, Maosen Lin ${ }^{3, *}$, Qinglin Chen ${ }^{4}$, Qingxuan Lu ${ }^{1}$, Jing Yao ${ }^{5}$ and Xingyuan He ${ }^{5}$ \\ 1 Liaoning Key Laboratory of Urban Integrated Pest Management and Ecological Security, College of Life \\ Science and Engineering, Shenyang University, Shenyang 110044, China; zlliu@syu.edu.cn (Z.L.); \\ lqx0812@syu.edu.cn (Q.L.) \\ 2 Academy of Forest and Grassland Inventory and Planning of National Forestry and \\ Grassland Administration, Beijing 100714, China; bumblebear17@163.com \\ 3 College of Water Conservancy, Shenyang Agricultural University, Shenyang 110866, China \\ 4 Forestry Development Service Center of Liaoning, Shenyang 110036, China; faximcq1@163.com \\ 5 CAS Key Laboratory of Forest Ecology and Management, Institute of Applied Ecology, \\ Shenyang 110016, China; yaojing@iae.ac.cn (J.Y.); hexy@iae.ac.cn (X.H.) \\ * Correspondence: lms@syau.edu.cn
}

Citation: Liu, Z.; Chen, M.; Lin, M.; Chen, Q.; Lu, Q.; Yao, J.; He, X. Cadmium Uptake and Growth Responses of Seven Urban Flowering Plants: Hyperaccumulator or Bioindicator? Sustainability 2022, 14, 619. https://doi.org/10.3390/ su14020619

Academic Editor: Simon Bell

Received: 8 November 2021 Accepted: 21 December 2021 Published: 6 January 2022

Publisher's Note: MDPI stays neutral with regard to jurisdictional claims in published maps and institutional affiliations.

Copyright: (C) 2022 by the authors. Licensee MDPI, Basel, Switzerland. This article is an open access article distributed under the terms and conditions of the Creative Commons Attribution (CC BY) license (https:// creativecommons.org/licenses/by/ $4.0 /)$.

\begin{abstract}
The application of flowering plants is the basis of urban forest construction. A newly-found flowering hyperaccumulator is crucial for remediating urban contaminated soil sustainably by cadmium (Cd). This study evaluated growth responses, $\mathrm{Cd}$ uptake and bioaccumulation characteristics of seven urban flowering plants. Based on growth responses of these plants, Calendula officinalis $\mathrm{L}$. showed high tolerance to at least $100 \mathrm{mg} \mathrm{kg}^{-1} \mathrm{Cd}$, in terms of significant increase in biomass and with no obvious changes in height. After $60 \mathrm{~d}$ exposure to $100 \mathrm{mg} \mathrm{kg}^{-1} \mathrm{Cd}$, the accumulated Cd in shoots of the plant reached $279.51 \pm 13.67 \mu \mathrm{g} \mathrm{g}^{-1} \mathrm{DW}$, which is above the critical value defined for a hyperaccumulator $\left(100 \mathrm{\mu g} \mathrm{g}^{-1} \mathrm{DW}\right.$ for $\left.\mathrm{Cd}\right)$. Meanwhile, the plant could accumulate $\mathrm{Cd}$ to as much as $926.68 \pm 29.11 \mu \mathrm{g} \mathrm{g}^{-1} \mathrm{DW}$ in root and $1206.19 \pm 23.06 \mu \mathrm{g} \mathrm{g}^{-1} \mathrm{DW}$ in plant, and had higher Cd uptake and bioaccumulation values. According to these traits, it is shown that Calendula officinalis L. can become a potential Cd-hyperaccumulator for phytoremediation. By contrast, Dianthus caryophyllus L. is very sensitive to Cd stress in terms of significantly decreased biomass, height and Cd uptake, indicating the plant is considered as a Cd-bioindicator.
\end{abstract}

Keywords: hyperaccumulation; cadmium; urban forest; remediation; environmental sustainable development

\section{Introduction}

Urban areas have become seriously contaminated zones by heavy metals derived from high density population and intensive industry within relatively limited space [1-8]. Heavy metal (HMs) contamination is commonly associated with the rapid development of urbanization, industrialization, manufacturing and mining, which pose an increasing threat to human health and eventually destroying the sustainable development of ecological environment [9-13]. Among these HMs, cadmium (Cd) is considered as one of the most toxic pollutants [14-20]. Cd is a non-essential element for most plants with highmobility and persistent toxicity in environmental media, which cause harmful effect on plant growth and finally enter the human body through the food chain [21-29]. Therefore, the soil remediation of $\mathrm{Cd}$ contamination in urban areas has attracted global attention due to the significant risk of $\mathrm{Cd}$ including teratogenic and carcinogenicity effects to human health [30-33].

A great number of current technologies have been developed to clean up the contaminated soil by $\mathrm{Cd}$ [34-36]. However, several conventional technologies, such as physical and chemical treatment approaches, are more expensive, less eco-friendly and bring secondary pollution problems [37-39]. In comparison, phytoremediation is considered as a promising 
green technique, which has the favourable characteristics of being in-situ, low-cost and eco-friendly [40-44]. Phytoremediation mainly relies on the use of hyperaccumulators, which can remove, assimilate or adsorb hazardous pollutants from soil [45-48]. Hyperaccumulators are the plants that accumulate about 100 times more heavy metals in shoots compared with normal plants, i.e., $100 \mu \mathrm{g} \mathrm{g}^{-1}$ for $\mathrm{Cd}[49,50]$. Owing to the limited number, slow growth rate and low biomass of the known $\mathrm{Cd}$ hyperaccumulators, phytoremediation has certain limitations in practice $[51,52]$. Thus, it is particularly important to explore new Cd hyperaccumulators $[5,53,54]$.

As the human living standards and urban landscapes improve, more and more ornamental plants are widely used for gardening and greening in urban areas $[1,55,56]$. Ornamental plants have surrounded humans living environmentally since the Neolithic period and have appeared in early Chinese poems and paintings, Egyptian pyramid morals and European history, indicating that humans have a long history of being attracted to ornamental plants $[57,58]$. Nowadays, ornamental plants, especially flowering plants, are an important part of urban forests, which are planted across all urban areas for enhancing the visual and aesthetic quality of the architectural environments, tolerating the stress of copper $(\mathrm{Cu})$, deicing reagents and drought stress, improving the air quality and fungal disease management, remediating the pollution of on-site greywater, eutrophication, ozone, VOCs, lead $(\mathrm{Pb})$, tin $(\mathrm{Sn})$ and petroleum hydrocarbons [59-69]. Ornamental plants are a more viable choice with high diversity and abundance $[1,6]$. Therefore, it could be predicted that HMs phytoremediation through flowering plants will bring more economic, environmental and social benefits to human living [18,51]. The application of flowering plants in urban areas not only cleans up the soil contaminated by HMs, but also contributes to beautification and decoration of the living environment.

In the present study, seven flowing plants widely used in urban areas all over China, namely, Orychophragmus violaceus (L.) O. E. Schulz., Impatiens balsamina L., Pelargonium hortorum Bailey., Mirabilis jalapa L., Althaea rosea (Linn.) Cavan., Calendula officinalis L. and Dianthus caryophyllus L. were selected. The objective of the study was: (1) to evaluate the growth responses of the seven flowering plants under the stress of different $\mathrm{Cd}$ concentrations in soil; (2) to identify Cd uptake and bioaccumulation characteristics of the seven flowering plants; and (3) to assess the pollutant sensitivity of the seven flowering plants as hyperaccumulators or bioindicators. Moreover, this study can provide a useful basis for screening new hyperaccumulators with the aim of remediating Cd-contaminated soil in urban areas and ensuring the sustainable development of the ecological environment.

\section{Materials and Methods}

\subsection{Plant Culture and $\mathrm{Cd}$ Exposure}

The pot-culture experiment was carried out in July 2020 at the agricultural experimental field of Shenyang Agricultural University $\left(41^{\circ} 44^{\prime} \mathrm{N}\right.$ and $123^{\circ} 27^{\prime} \mathrm{E}, 44.7 \mathrm{~m}$ a.s.l.), which is in the temperate zone with a continental monsoon climate. The average annual temperature is $8.0^{\circ} \mathrm{C}$, the average annual precipitation is $702.9 \mathrm{~mm}$ and the relative air humidity is $65-75 \%$. The soil used in the pots was collected from the topsoil $(0-20 \mathrm{~cm})$ of the experimental field. The physical and chemical properties of the test soil was listed in Table 1. The air-dried soil samples were sieved through a 3-mm mesh sieve and placed into plastic pots with $(20 \mathrm{~cm}$ diameter $\times 15 \mathrm{~cm}$ height $)$ and mixed uniformly with the specified concentration of $\mathrm{CdCl}_{2} \cdot 2.5 \mathrm{H}_{2} \mathrm{O}$ solution. Three $\mathrm{Cd}$ concentrations were applied: 0 (the control), 10 and $100 \mathrm{mg} \mathrm{kg}^{-1}$. Seeds of seven flowering plants (Orychophragmus violaceus (L.) O. E. Schulz., Impatiens balsamina L., Pelargonium hortorum Bailey., Mirabilis jalapa L., Althaea rosea (Linn.) Cavan., Calendula officinalis L. and Dianthus caryophyllus L.) were obtained from Liaoning Academy of Agricultural Sciences. The natural properties of sampled plants were listed in Table 2. Thirty seeds of each flowering plant were transplanted into each pot. After one month of growth, uniform seedlings with similar size and height were transplanted into the pots (ten seedlings per pot). All the pots were randomly arranged in a constant temperature room under the controlled conditions $\left(100-150 \mu \mathrm{mol} \mathrm{m}^{-2} \mathrm{~s}^{-1}\right.$ light intensity, 
16/8 h light/dark, $25 / 20{ }^{\circ} \mathrm{C}$ at day/night, $60-70 \%$ relative humidity). Nitrogen fertilizer as $\mathrm{NH}_{4} \mathrm{NO}_{3}$ was added in soil at $40 \mathrm{mg} \mathrm{kg}^{-1}$ and foliar spraying with $0.2 \% \mathrm{KH}_{2} \mathrm{PO}_{4}$ was applied for all treatments every 10 days to ensure the normal nutrient supply of plant growth. Each $\mathrm{Cd}$ concentration was repeated four times in separate pots. The flowering plants were cultivated for $60 \mathrm{~d}$ and the soil analyzed later.

Table 1. The physical and chemical properties of the test soil.

\begin{tabular}{ll}
\hline Parameters & Soil \\
\hline Type & Meadow \\
\hline $\mathrm{pH}$ & $7.29 \pm 0.02$ \\
\hline Cation exchange capacity $(\mathrm{CEC})\left(\mathrm{cmol}+\mathrm{kg}^{-1}\right)$ & $19.17 \pm 0.06$ \\
\hline Organic matter $\left(\mathrm{g} \mathrm{kg}^{-1}\right)$ & $20.65 \pm 0.08$ \\
\hline Total $\mathrm{N}\left(\mathrm{g} \mathrm{kg}^{-1}\right)$ & $0.89 \pm 0.01$ \\
\hline Available $\mathrm{P}\left(\mathrm{mg} \mathrm{kg}^{-1}\right)$ & $8.83 \pm 0.07$ \\
\hline Available K $\left(\mathrm{mg} \mathrm{kg}^{-1}\right)$ & $75.52 \pm 0.05$ \\
\hline Clay/\% & $32.09 \pm 0.11$ \\
\hline Sand/\% & $21.75 \pm 0.06$ \\
\hline Silt/\% & $44.12 \pm 0.05$ \\
\hline Available Ca $\left(\mathrm{g} \mathrm{kg}^{-1}\right)$ & $2.38 \pm 0.04$ \\
\hline Available Mg $\left(\mathrm{g} \mathrm{kg}^{-1}\right)$ & $0.61 \pm 0.02$ \\
\hline Cd $\left(\mathrm{mg} \mathrm{kg}{ }^{-1}\right)$ & $0.16 \pm 0.03$ \\
\hline
\end{tabular}

\subsection{Plant and Soil Analysis}

When the experiment was terminated, four plants with similar growth character were chosen in each treatment, and the height of these plants was recorded. The harvested plant materials were rinsed with tap water, and the roots were immersed in $20 \mathrm{mM} \mathrm{Na} \mathrm{m}_{2}$-EDTA for $20 \mathrm{~min}$ to clear $\mathrm{Cd}$ adhered to the root surface [18,42]. Then, the plants were divided into shoots and roots. The separated plant materials were rinsed with running tap water and distilled water, wiped with tissues and weighed. They were then dried at $105{ }^{\circ} \mathrm{C}$ for $30 \mathrm{~min}$, then at $70{ }^{\circ} \mathrm{C}$ until weight was constant for $\mathrm{Cd}$ content measurement. The biomass (dry weight) of the plant materials was recorded.

The powders $(0.5 \mathrm{~g})$ of the harvested plant materials were digested with a concentrated acid mixture of $\mathrm{HNO}_{3} / \mathrm{HClO}_{4}(3: 1, v / v)$. The plant samples were then incubated at $60{ }^{\circ} \mathrm{C}$ for two hours (open vessel digestion). The digested plant samples were incubated overnight at room temperature. They were diluted, filtered using filter paper (Whatman Grade 1) and cellulose acetate syringe filters. The soil materials were sieved and dried overnight at $65{ }^{\circ} \mathrm{C}$ before acid digestion in $\mathrm{HCl} / \mathrm{HNO}_{3}(3: 1, v / v)$. The soil samples were incubated overnight at room temperature. They were then filtered twice using filter paper (Whatman Grade 1) and once using cellulose acetate syringe filters (Whatman Grade 1). The concentrations of $\mathrm{Cd}$ in plant tissues and soils were determined with an inductively coupled plasma mass spectrometry instrument (ICP-MS, Agilent 7900, Agilent Technologies, Tokyo, Japan) [5,25].

The physical and chemical properties of the soils were measured using the analytical methods for soils and agricultural chemistry [70]. Soil pH was determined by a glass electrode $\mathrm{pH}$ meter in a 1:2.5 soil-water slurry. The CEC was determined using a $\mathrm{NH}_{4}$ acetate compulsory displacement method. Soil organic matter was determined by the $\mathrm{K}_{2} \mathrm{Cr}_{2} \mathrm{O}_{7}$ titration method after digestion. Total $\mathrm{N}$ of the soil was determined by $\mathrm{H}_{2} \mathrm{SO}_{4}$ digestion followed by steam distillation with $25 \mathrm{~mL} \mathrm{NaOH}\left(10 \mathrm{~mol} \mathrm{~L}^{-1}\right)$ and titration with $5 \mathrm{mmol} \mathrm{L}^{-1} \mathrm{H}_{2} \mathrm{SO}_{4}$, and analyzed using an element analyzer (Vario MACRO cube, Elementar Inc., Germany). Available P was extracted with $0.5 \mathrm{~mol} \mathrm{~L}^{-1} \mathrm{NaHCO}_{3}(\mathrm{pH}=8.5)$ and then determined by colorimetric analysis. Available $\mathrm{K}$ was extracted with $1 \mathrm{~mol} \mathrm{~L}^{-1}$ 
$\mathrm{CH}_{3} \mathrm{COONH}_{4}(\mathrm{pH}=7.0)$ solution, and measured with an inductively coupled plasma mass spectrometry instrument (ICP-MS, Agilent 7900, Japan). Soil particle size distribution was determined by pipette method. Available $\mathrm{Ca}$ and $\mathrm{Mg}$ were extracted with the Mehlich 3 extractant and measured by atomic absorption spectroscopy (AAS, Hitachi Z-8000, Hitachi High-Tech, Tokyo, Japan) [71].

Table 2. The natural properties of seven flowering plants.

\begin{tabular}{|c|c|c|c|}
\hline Plant Species & Families and Genera & Life Form & Plant Images \\
\hline $\begin{array}{c}\text { Orychophragmus violaceus (L.) } \\
\text { O. E. Schulz }\end{array}$ & Cruciferae, Orychophragmus & Annual or biennial & \\
\hline Impatiens balsamina L. & Balsaminaceae, Impatiens & Annual & \\
\hline Pelargonium hortorum Bailey & Geraniaceae, Pelargonium & Perennial & \\
\hline Mirabilis jalapa L. & Nyctaginaceae, Zinnia & Annual & \\
\hline Althaea rosea (Linn.) Cavan. & Malvaceae, Althaea & Biennial & \\
\hline Calendula officinalis L. & Asteraceae, Calendula & Annual & \\
\hline Dianthus caryophyllus L. & Caryophyllaceae, Dianthus & Perennial & \\
\hline
\end{tabular}

\subsection{Data Analysis}

The bioaccumulation factor $(\mathrm{BCF})$ indicated the ability of plants to accumulate heavy metals from soils [51,54]. BCF was calculated as:

$$
\mathrm{BCF}=\frac{\text { the metal concentration in plant tissues }}{\text { the metal concentration in soils }}
$$

Heavy-metal uptake was calculated using the following formula as [41]. 


$$
\operatorname{Uptake}\left(\mu \mathrm{g} \text { plant }^{-1} \mathrm{~d}^{-1}\right)=\frac{\mathrm{M}_{2} \mathrm{~W}_{2}-\mathrm{M}_{1} \mathrm{~W}_{1}}{\mathrm{~T}_{2}-\mathrm{T}_{1}}
$$

Where $\mathrm{M}_{1}$ and $\mathrm{M}_{2}$ are metal concentrations in the plant tissue and $\mathrm{W}_{1}$ and $\mathrm{W}_{2}$ are the plant biomass at time $\mathrm{T}_{1}$ (initial sampling) and $\mathrm{T}_{2}$ (final sampling).

\subsection{Statistical Analyses}

All measurements were replicated four times. Means and standard deviations (SD) were calculated by the Microsoft Office Excel 2016 for all the data. One-way ANOVA was carried out with SPSS 22.0. The significant difference was set between treatments at $p<0.05$ or $p<0.01$. Multiple comparison was also made by the least significant difference (LSD) test.

\section{Results and Discussion}

\subsection{Growth Responses of the Seven Flowering Plants}

\subsubsection{Differences in Biomass among the Seven Flowering Plants}

Heavy metal $\mathrm{Cd}$ is a non-essential element for plant growth and has different effects on different plant species and tissues [14,22,26,29,72]. As shown in Figure 1, after $60 \mathrm{~d}$ exposure to $10 \mathrm{mg} \mathrm{kg}^{-1} \mathrm{Cd}$, the shoot biomass DW of the four flowering plants (Orychophragmus violaceus (L.) O. E. Schulz, Impatiens balsamina L., Mirabilis jalapa L., Althaea rosea (Linn.) Cavan.) showed no significant differences compared with the control. By contrast, the shoot biomass DW of Pelargonium hortorum Bailey and Calendula officinalis L. increased significantly $(p<0.01)$. When the Cd concentration in soil reached $100 \mathrm{mg} \mathrm{kg}^{-1}$, the shoot biomass DW of Calendula officinalis L. still had a significant increase compared with the control. The increase of $\mathrm{Cd}$ concentration in soil led to the shoot biomass (dry weight) of the two flowering plants (Pelargonium hortorum Bailey and Althaea rosea (Linn.) Cavan.) showing a significant decrease $(p<0.05)$, and the shoot biomass DW of Impatiens balsamina L. showed no significant differences compared with the control. Under the treatment of different $\mathrm{Cd}$ concentrations (10 and $100 \mathrm{mg} \mathrm{kg}^{-1}$ ) in soil, interveinal chlorosis, gradually whole leaf chlorosis on the leaves of Dianthus caryophyllus L. were found, and the shoot biomass (dry weight) of the plant decreased significantly by $42 \%$ and $85 \%$ compared with the control $(p<0.01)$.

When the plants were exposed to $10 \mathrm{mg} \mathrm{kg}^{-1} \mathrm{Cd}$, the root biomass DW of the four flowering plants (Orychophragmus violaceus (L.) O. E. Schulz, Impatiens balsamina L., Althaea rosea (Linn.) Cavan., Calendula officinalis L.) increased to different extents compared with the control, which indicated similar increased phenomenon with the shoot growth. The increase of $\mathrm{Cd}$ concentration in soil led to the root biomass DW of the three flowering plants (Pelargonium hortorum Bailey Mirabilis jalapa L. and Dianthus caryophyllus L.) showing a significant decrease compared with the control $(p<0.01)$. As shown as in Figure 1 , the total biomass DW of the seven flowering plants showed a similar change trend with the shoot biomass DW of these plants.

On the whole, after $60 \mathrm{~d}$ exposure to $10 \mathrm{mg} \mathrm{kg}^{-1} \mathrm{Cd}$, the shoot, root and total biomass DW of Calendula officinalis L. had a significant increase $(p<0.01)$, indicating that low concentration $\mathrm{Cd}$ in soil could have a stimulating influence on plant growth. The similar phenomenon has been reported by other researchers $[18,26,73-75]$, which is also proposed as hormesis by Liu et al. (2015) [76]. When the Cd concentration in soil reached to $100 \mathrm{mg} \mathrm{kg}^{-1}$, the shoot, root and total biomass DW of Calendula officinalis L. still increased to different extents compared with the control, showing that the plant had a good tolerance to Cd stress. By contrast, under the treatment of different $\mathrm{Cd}$ concentrations in soil, the shoot, root and total biomass DW of Dianthus caryophyllus L. all showed a significant decrease compared with the control $(p<0.01)$, illustrating that Dianthus caryophyllus L. is very sensitive to $C d$ stress. 

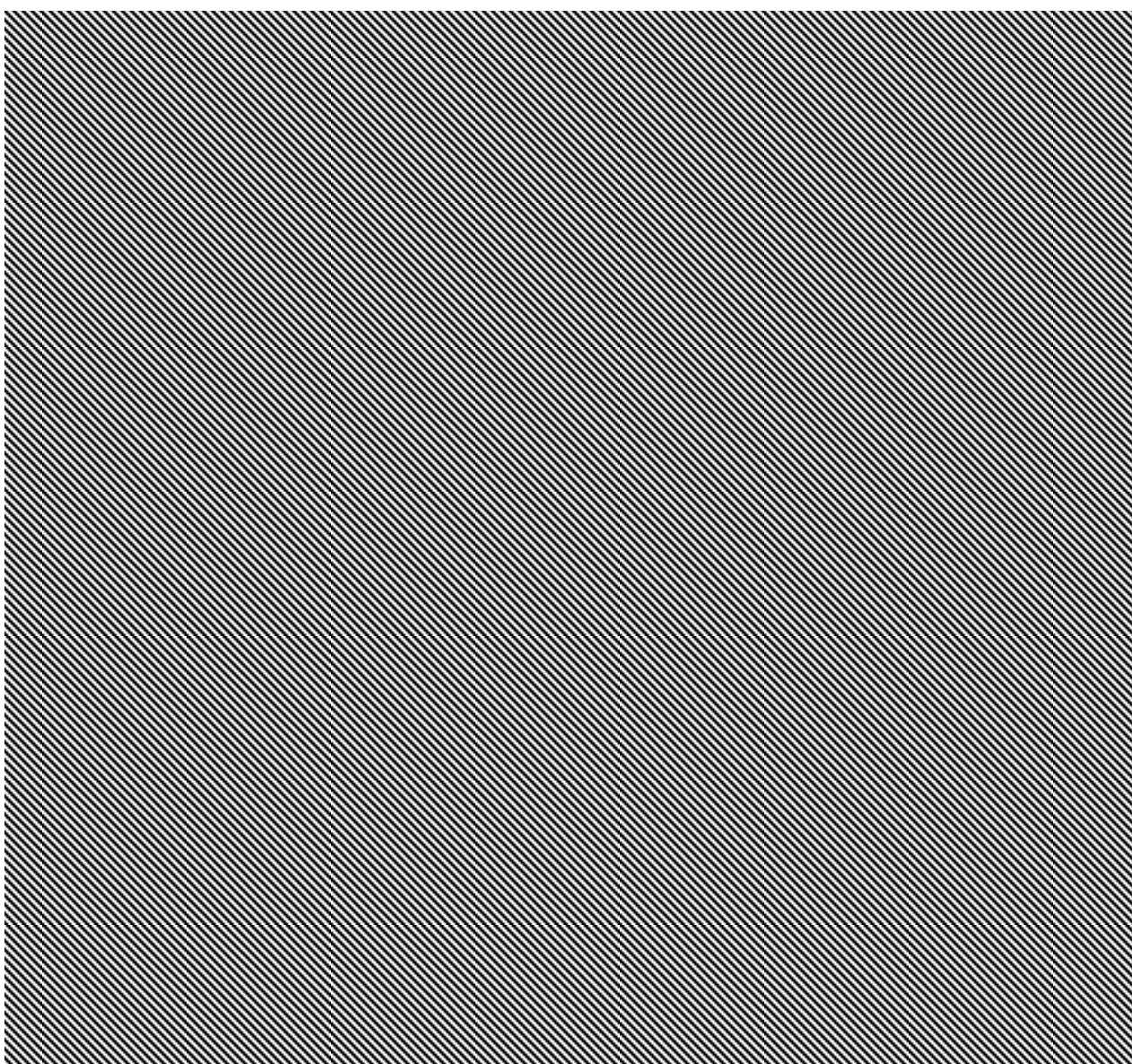

Figure 1. Effects of Cd soil concentrations on shoots, root and total biomass DW of seven flowering plants. Values represent mean \pm SD.

\subsubsection{Differences in Height among the Seven Flowering Plants}

As shown as in Figure 2, after $60 \mathrm{~d}$ exposure to $10 \mathrm{mg} \mathrm{kg}^{-1} \mathrm{Cd}$, the height of the four plants (Orychophragmus violaceus (L.) O. E. Schulz., Pelargonium hortorum Bailey., Mirabilis jalapa L., Althaea rosea (Linn.) Cavan.) showed no significant differences, and the height of Impatiens balsamina L. and Calendula officinalis L. showed a significant increase compared with the control $(p<0.01)$, which is also consistent with other studies $[35,42,48,53]$. The hormesis phenomenon of the plant height is similar with the above biomass changes, which may originate from the internal defense mechanism induced by oxidative free radicals or the overcompensation response of plant cells or organisms to toxic pollutants. The underlying mechanism research needs to be further studied. when the $\mathrm{Cd}$ concentration in soil reached $100 \mathrm{mg} \mathrm{kg}^{-1}$, the height of the four plants (Orychophragmus violaceus (L.) O. E. Schulz., Impatiens balsamina L., Mirabilis jalapa L., Calendula officinalis L.) showed no significant differences compared with the control. By contrast, under the treatment of different Cd concentrations (10 and $100 \mathrm{mg} \mathrm{kg}^{-1}$ ) in soil, the height of Dianthus caryophyllus L. all decreased significantly by $11 \%$ and $32 \%$ compared with the control $(p<0.01)$, which is in agreement with the change of the shoot, root and total biomass DW of the plant, reconfirming the sensitivity of Dianthus caryophyllus L. to Cd stress.

Based on the growth responses of the seven flowering plants, results showed that Calendula officinalis L. had high tolerance to not less than $100 \mathrm{mg} \mathrm{kg}^{-1} \mathrm{Cd}$, which shows significant increases in biomass and no obvious changes in height. The growth of Calendula officinalis L. was increased at the low Cd concentration $\left(10 \mathrm{mg} \mathrm{kg}^{-1}\right)$, which is conducive for the plant to adapt to external stress. These growth traits indicated that Calendula officinalis $\mathrm{L}$. has good potential in Cd-contaminated remediation, since the tolerance of plant to heavy metal toxicity could provide an important reference to distinguish a 
hyperaccumulator $[26,41,42,45,50]$. By contrast, Dianthus caryophyllus L. is very sensitive to Cd stress showing decreased biomass and height, which indicated the plant is considered as a Cd-bioindicator.

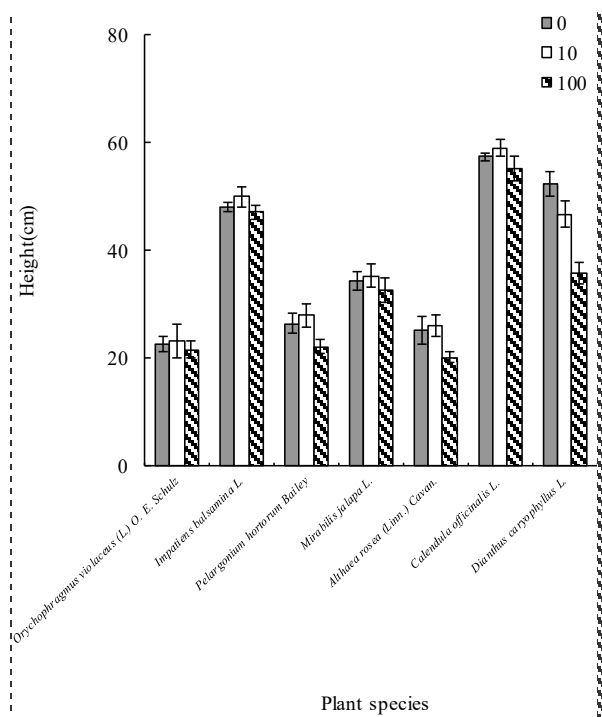

Figure 2. Effects of $\mathrm{Cd}$ soil concentrations on height of seven flowering plants. Values represent mean \pm SD.

\subsection{Accumulation Characteristics of the Seven Flowering Plants}

3.2.1. Differences in Cd Accumulation among the Seven Flowering Plants

After $60 \mathrm{~d}$ Cd-exposure, the effects of $\mathrm{Cd}$ soil concentrations on $\mathrm{Cd}$ concentration in shoots, roots and plants of seven flowering plants are shown in Figure 3. Cd concentrations accumulated in shoots, roots and plants of the seven flowering plants all increased to different extents with increasing $\mathrm{Cd}$ concentrations in soil. When the $\mathrm{Cd}$ concentration in soil reached $100 \mathrm{mg} \mathrm{kg}^{-1}$, the concentrations of accumulated Cd in shoots of Orychophragmus violaceus (L.) O. E. Schulz., Impatiens balsamina L.,Mirabilis jalapa L. and Calendula officinalis L. reached $101.77 \pm 3.31,161.64 \pm 5.13,113.54 \pm 6.87$ and $279.51 \pm 13.67 \mu \mathrm{g} \mathrm{g}^{-1} \mathrm{DW}$, respectively, which is above the critical value defined for the hyperaccumulator $\left(100 \mu \mathrm{g} \mathrm{g}^{-1} \mathrm{DW}\right.$ for Cd) $[5,18,40,42,77]$. By comparison, the concentrations of accumulated Cd in shoots of Pelargonium hortorum Bailey., Althaea rosea (Linn.) Cavan. and Dianthus caryophyllus L. were only $34.75 \pm 2.95,58.19 \pm 3.05$ and $14.65 \pm 5.82 \mu \mathrm{g} \mathrm{g}^{-1} \mathrm{DW}$. At the same level of $\mathrm{Cd}$ concentration $\left(100 \mathrm{mg} \mathrm{kg}^{-1}\right)$ in soil, the concentrations of accumulated $\mathrm{Cd}$ in roots of Impatiens balsamina L. and Calendula officinalis L. reached $320.46 \pm 19.65$ and $926.68 \pm 29.11 \mathrm{\mu g} \mathrm{g}^{-1} \mathrm{DW}$, respectively. The roots of Calendula officinalis L. were able to hyperaccumulate impressive concentrations of Cd $\left(926.68 \pm 29.11 \mu \mathrm{g} \mathrm{g}^{-1} \mathrm{Cd}\right)$ far exceeding other hyperaccumulator species, such as Tagetes patula L. (273.77 $\mathrm{mg} \mathrm{kg}^{-1}$ ) [20]. However, the concentrations of accumulated Cd in roots of Orychophragmus violaceus (L.) O. E. Schulz., Pelargonium hortorum Bailey., Mirabilis jalapa L., Althaea rosea (Linn.) Cavan. And Dianthus caryophyllus L. were all less than $57 \mu \mathrm{g} \mathrm{g}^{-1}$ DW. Under the treatment of low Cd concentrations $\left(10 \mathrm{mg} \mathrm{kg}^{-1}\right)$ in soil, the concentrations of accumulated $\mathrm{Cd}$ in plants of Impatiens balsamina L.and Calendula officinalis L. were $106.86 \pm 15.83$ and $134.85 \pm 31.07 \mu \mathrm{g} \mathrm{g}^{-1} \mathrm{DW}$, respectively, and the concentrations of accumulated $\mathrm{Cd}$ in roots of the other five flowering plants were all less than $54.00 \mu \mathrm{g} \mathrm{g}^{-1} \mathrm{DW}$. Due to the increase of Cd concentration in soil, the concentrations of accumulated Cd in Impatiens balsamina L. and Calendula officinalis L. reached $482.10 \pm 40.19$ and $1206.19 \pm 23.06 \mu^{-1} \mathrm{~g}^{-1} \mathrm{DW}$, and the concentrations of accumulated $\mathrm{Cd}$ in the other five flowering plants were all less than $165.00 \mu \mathrm{g} \mathrm{g}^{-1} \mathrm{DW}$, especially for Dianthus caryophyllus L., the concentrations of accumulated Cd in plants were only $71.27 \pm 37.04 \mu \mathrm{g} \mathrm{g}^{-1} \mathrm{DW}$. 

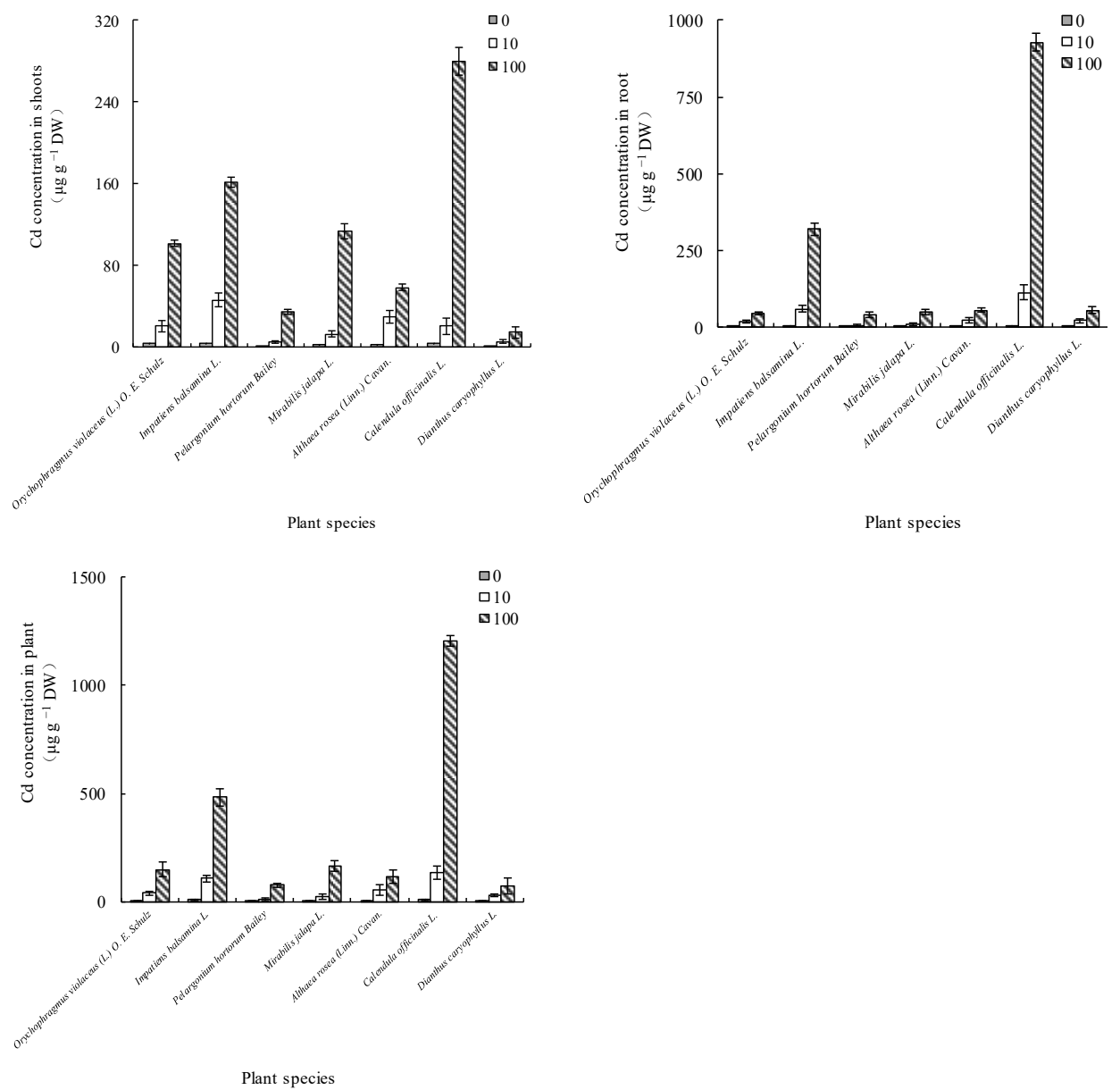

Figure 3. Effects of $\mathrm{Cd}$ soil concentrations on $\mathrm{Cd}$ concentration in shoots, roots and plants of seven flowering plants. Values represent mean \pm SD.

Differences in $\mathrm{Cd}$ accumulation among the seven flowering plants indicated that Calendula officinalis $\mathrm{L}$. had a good accumulation ability for $\mathrm{Cd}$, in terms of the high concentrations of accumulated Cd in shoots, roots and plants. By contrast, Dianthus caryophyllus L. had a poor accumulation ability for $\mathrm{Cd}$. The different traits of $\mathrm{Cd}$ accumulation in Calendula officinalis L. and Dianthus caryophyllus L. had a good correlation with growth responses of the two plants.

\subsubsection{Differences in $\mathrm{Cd}$ Uptake and BCF among the Seven Flowering Plants}

As shown as Table 3, Cd uptake and $\mathrm{BCF}$ of seven flowering plants varied with the increase of $\mathrm{Cd}$ concentrations in the soil. When the concentration of $\mathrm{Cd}$ was $10 \mathrm{mg} \mathrm{kg}^{-1}$ in soil, Cd uptake of Calendula officinalis $\mathrm{L}$. were $8.13 \pm 0.08 \mu \mathrm{g}$ plant ${ }^{-1} \mathrm{~d}^{-1}$, which was higher than six other plants. By contrast, Cd uptake of Dianthus caryophyllus L. was only $0.69 \pm 0.03$. When the concentration of Cd reached $100 \mathrm{mg} \mathrm{kg}^{-1}$ in soil, Cd uptake of Calendula officinalis L. increased significantly and reached $80.77 \pm 0.19 \mu \mathrm{g} \mathrm{plant}{ }^{-1} \mathrm{~d}^{-1}$, and Cd uptake of the six other plants were all less than $14.00 \mu \mathrm{g} \mathrm{plant}^{-1} \mathrm{~d}^{-1}$, especially for Dianthus caryophyllus L., only $0.43 \pm 0.02$. There was a positive correlation between $\mathrm{Cd}$ uptake and Cd concentrations accumulated in Calendula officinalis L., indicating that the plant may accumulate larger amounts of $\mathrm{Cd}$ when exposed to higher $\mathrm{Cd}$ concentrations in soil.

The bioconcentration factor (BCF) was used to evaluate the efficacy of the plant to accumulate the toxic pollutants in plant tissues [51,53,78]. When the concentration of $\mathrm{Cd}$ was $10 \mathrm{mg} \mathrm{kg}^{-1}$ in soil, the BCF values of Impatiens balsamina L. and Calendula officinalis L. were 10.69 and 13.49, which was higher than the other five plants. When the concentration 
of Cd reached $100 \mathrm{mg} \mathrm{kg}^{-1}$ in soil, the BCF values of Calendula officinalis L. was 12.06 , which was still higher than the other six plants, indicating that the plant can accumulate $\mathrm{Cd}$ more efficiently and still maintain high efficiency even if the concentration of $\mathrm{Cd}$ in soil was above $100 \mathrm{mg} \mathrm{kg}^{-1}$. On the contrary, the BCF values of Dianthus caryophyllus L. was only 0.71 , which was in accordance with the poor ability for $\mathrm{Cd}$ uptake and $\mathrm{Cd}$ concentrations accumulated in the plant. Based on higher Cd uptake and BCF values, the higher concentrations of accumulated $\mathrm{Cd}$ in shoots, roots and plants of Calendula officinalis $\mathrm{L}$. showed that the plant has the potential of hyperaccumulation used for phytoremediation of Cd-contaminated soils.

Table 3. Effects of Cd soil concentrations on Cd uptake and BCF of seven flowering plants.

\begin{tabular}{|c|c|c|c|c|c|c|}
\hline \multirow{2}{*}{ Plant Species } & \multicolumn{3}{|c|}{ Cd Uptake ( $\mu$ g plant $\left.{ }^{-1} d^{-1}\right)$} & \multicolumn{3}{|c|}{ BCF in Plants } \\
\hline & 0 & 10 & 100 & 0 & 10 & 100 \\
\hline Orychophragmus violaceus (L.) O. E. Schulz & $0.10 \pm 0.01$ & $0.71 \pm 0.03$ & $2.40 \pm 0.05$ & & 3.94 & 1.47 \\
\hline Impatiens balsamina $\mathrm{L}$. & $0.22 \pm 0.03$ & $3.30 \pm 0.07$ & $13.77 \pm 0.16$ & & 10.69 & 4.82 \\
\hline Pelargonium hortorum Bailey & $0.08 \pm 0.01$ & $1.68 \pm 0.05$ & $6.35 \pm 0.13$ & & 1.10 & 0.76 \\
\hline Mirabilis jalapa L. & $0.31 \pm 0.01$ & $1.26 \pm 0.06$ & $8.97 \pm 0.13$ & & 2.29 & 1.64 \\
\hline Althaea rosea (Linn.) Cavan. & $0.08 \pm 0.01$ & $0.86 \pm 0.03$ & $0.73 \pm 0.08$ & & 5.36 & 1.14 \\
\hline Calendula officinalis L. & $0.39 \pm 0.05$ & $8.13 \pm 0.08$ & $80.77 \pm 0.19$ & & 13.49 & 12.06 \\
\hline Dianthus caryophyllus L. & $0.16 \pm 0.03$ & $0.69 \pm 0.03$ & $0.43 \pm 0.02$ & & 2.72 & 0.71 \\
\hline
\end{tabular}

\section{Conclusions}

Firstly, Calendula officinalis L., as a popular ornamental flowering plant, has been historically grown throughout the world and produced commercially in Europe and the US, which benefits from the easy and rapid growth of the plant for flower or seed production $[79,80]$. Secondly, seeds of Calendula officinalis L. are rich in calendic acid, which can substitute for volatile organic compounds (VOCs) as a drying agent in many industrial chemicals [81,82]. As urban residents' demands for renewable, environmentally friendly alternatives for VOCs are growing, Calendula officinalis L. may serve as an attractive oil crop for promoting sustainable urban development. Furthermore, in our present study, it was shown that Calendula officinalis L. had a good tolerance to Cd stress; at the same time, among the seven flowering plants, Calendula officinalis L. showed a better accumulation ability of $\mathrm{Cd}$, above the critical value defined for the hyperaccumulator $\left(100 \mu \mathrm{g} \mathrm{g}^{-1} \mathrm{DW}\right.$ for $\left.\mathrm{Cd}\right)$ and had higher $\mathrm{Cd}$ uptake and $\mathrm{BCF}$ values. According to these traits above, it is shown Calendula officinalis L. can become a good hyperaccumulator used for phytoremediation of environmental pollution in urban areas. The present study will provide an available reference for exploring $\mathrm{Cd}$ tolerant strategies in hyperaccumulator or bioindicators, and will also contribute to healthy urban residents' well-being and sustainable development of urban forests.

Author Contributions: Conceptualization, Z.L., Q.L., X.H. and M.L.; data curation, Z.L. and M.C.; formal analysis, Z.L. and M.L.; funding acquisition, M.L.; methodology, Z.L. and Q.C.; software, Z.L., J.Y. and M.L.; writing-original draft, Z.L.; writing-review and editing, Z.L., Q.L. and M.L. All authors have read and agreed to the published version of the manuscript.

Funding: This research was supported by the Young Scientists Fund of the National Natural Science Foundation of China (41807172).

Institutional Review Board Statement: Not applicable.

Informed Consent Statement: Not applicable.

Data Availability Statement: The data presented in this study are available on request from the corresponding author. The data are not publicly available due to the restriction policy of co-authors' affiliations.

Conflicts of Interest: The authors declare no conflict of interest. 


\section{References}

1. Carrus, G.; Scopelliti, M.; Lafortezza, R.; Colangelo, G.; Ferrini, F.; Salbitano, F.; Agrimi, M.; Portoghesi, L.; Semenzato, P.; Sanesi, G. Go greener, feel better? The positive effects of biodiversity on the well-being of individuals visiting urban and peri-urban green areas. Landsc. Urban Plan. 2015, 134, 221-228. [CrossRef]

2. Boim, A.G.F.; Melo, L.C.A.; Moreno, F.N.; Alleoni, L.R.F. Bioconcentration factors and the risk concentrations of potentially toxic elements in garden soils. J. Environ. Manag. 2016, 170, 21-27. [CrossRef] [PubMed]

3. Hwang, H.-M.; Fiala, M.J.; Park, D.; Wade, T.L. Review of pollutants in urban road dust and stormwater runoff: Part 1. Heavy metals released from vehicles. Int. J. Urban Sci. 2016, 20, 334-360. [CrossRef]

4. Wang, Y.Q.; Bai, Y.R.; Wang, J.Y. Distribution of urban soil heavy metal and pollution evaluation in different functional zones of Yinchuan city. Environ. Sci. 2016, 37, 710-716.

5. Midhat, L.; Ouazzani, N.; Esshaimi, M.; Ouhammou, A.; Mandi, L. Assessment of heavy metals accumulation by spontaneous vegetation: Screening for new accumulator plant species grown in Kettara mine-Marrakech, Southern Morocco. Int. J. Phytoremediat. 2017, 19, 191-198. [CrossRef] [PubMed]

6. Hou, S.; Wang, X.; Shafifi, M.; Penttinen, P.; Xu, W.; Ma, J.; Zhong, B.; Guo, J.; Xu, M.; Ye, Z.; et al. Remediation efficacy of Sedum plumbizincicola as affected by intercropping of landscape plants and oxalic acid in urban cadmium contaminated soil. J. Soils Sediments 2019, 19, 3512-3520. [CrossRef]

7. Men, C.; Liu, R.; Xu, L.; Wang, Q.; Guo, L.; Miao, Y.; Shen, Z. Source-specific ecological risk analysis and critical source identification of heavy metals in road dust in Beijing, China. J. Hazard. Mater. 2020, 388, 121763. [CrossRef]

8. Zeng, Z.; Luo, W.-G.; Yi, F.-C.; Huang, F.-Y.; Wang, C.-X.; Zhang, Y.-P.; Cheng, Q.-Q.; Wang, Z. Horizontal Distribution of Cadmium in Urban Constructed Wetlands: A Case Study. Sustainability 2021, 13, 5381. [CrossRef]

9. Dixit, R.; Malaviya, D.; Pandiyan, K.; Singh, U.B.; Sahu, A.; Shukla, R.; Singh, B.P.; Rai, J.P.; Sharma, P.K. Bioremediation of heavy metals from soil and aquatic environment: An overview of principles and criteria of fundamental processes. Sustainability 2015, 7 , 2189-2212. [CrossRef]

10. Asati, A.; Pichhode, M.; Nikhil, K. Effect of Heavy Metals on Plants: An Overview. Int. J. Appl. Innov. Eng. Manag. 2016, 5, 56-66.

11. Mahar, A.; Wang, P.; Ali, A.; Awasthi, M.K.; Lahori, A.H.; Wang, Q.; Li, R.; Zhang, Z. Challenges and opportunities in the phytoremediation of heavy metals contaminated soils: A review. Ecotox. Environ. Saf. 2016, 126, 111-121. [CrossRef] [PubMed]

12. Kwiatkowska-Malina, J. Functions of organic matter in polluted soils: The effect of organic amendments on phytoavailability of heavy metals. Appl. Soil Ecol. 2018, 123, 542-545. [CrossRef]

13. Yang, Q.; Li, Z.; Lu, X.; Duan, Q.; Huang, L.; Bi, J. A review of soil heavy metal pollution from industrial and agricultural regions in China: Pollution and risk assessment. Sci. Total Environ. 2018, 642, 690-700. [CrossRef]

14. Hart, J.J.; Welch, R.M.; Norvell, W.A.; Clarke, J.M.; Kochian, L.V. Zinc effects on cadmium accumulation and partitioning innear-isogenic lines of durum wheat that differ in grain cadmium concentration. New Phytol. 2005, 167, 391-401. [CrossRef] [PubMed]

15. Järup, L.; Åkesson, A. Current status of cadmium as an environmental health problem. Toxicol. Appl. Pharmacol. 2009, 238, 201-208. [CrossRef] [PubMed]

16. Joseph, P. Mechanisms of cadmium carcinogenesis. Toxicol. Appl. Pharmacol. 2009, 238, 272-279. [CrossRef]

17. Nordberg, G.F. Historical perspectives on cadmium toxicology. Toxicol. Appl. Pharmacol. 2009, 238, 192-200. [CrossRef]

18. Liu, Z.; Chen, W.; He, X. Influence of $\mathrm{Cd}^{2+}$ on growth and chlorophyll fluorescence in a hyperaccumulator-Lonicera japonica Thunb. J. Plant Growth Regul. 2015, 34, 672-676. [CrossRef]

19. Mahajan, P.; Kaushal, J. Role of phytoremediation in reducing cadmium toxicity in soil and water. J. Toxicol. 2018, 2018, 4864365 [CrossRef]

20. Sun, R.; Sun, Q.; Wang, R.; Cao, L. Cadmium accumulation and main rhizosphere characteristics of seven French marigold (Tagetes patula L.) cultivars. Int. J. Phytoremediat. 2018, 20, 1171-1178. [CrossRef]

21. Chowardhara, B.; Borgohain, P.; Saha, B.; Awasthi, J.P.; Moulick, D.; Panda, S.K. Phytotoxicity of Cd and Zn on three popular Indian mustard varieties during germination and early seedling growth. Biocatal. Agric. Biotechnol. 2019, 21, 101349. [CrossRef]

22. Fattahi, B.; Arzani, K.; Souri, M.K.; Barzegar, M. Effects of cadmium and lead on seed germination, morphological traits, and essential oil composition of sweet basil (Ocimum basilicum L.). Ind. Crop. Prod. 2019, 138, 111584. [CrossRef]

23. Jiang, M.; Jiang, J.; Li, S.; Li, M.; Tan, Y.; Song, S.; Shu, Q.; Huang, J. Glutamate alleviates cadmium toxicity in rice via suppressing cadmium uptake and translocation. J. Hazard. Mater. 2020, 384, 121319. [CrossRef] [PubMed]

24. Li, K.; Yin, G.C.; Xu, Q.Y.; Yan, J.H.; Hseu, Z.Y.; Zhu, L.W.; Lin, Q.T. Influence of aged biochar modified by Cd ${ }^{2+}$ on soil properties and microbial community. Sustainability 2020, 12, 4868. [CrossRef]

25. Fujimaki, S.; Suzui, N.; Ishioka, N.S.; Kawachi, N.; Ito, S.; Chino, M.; Nakamura, S.I. Tracing cadmium from culture to spikelet: Noninvasive imaging and quantitative characterization of absorption, transport, and accumulation of cadmium in an intact rice plant. Plant Physiol. 2010, 152, 1796-1806. [CrossRef]

26. Mohamed, A.; Castagna, A.; Ranieri, A.; di Toppi, L.S. Cadmium tolerance in Brassica juncea roots and shoots is affected by antioxidant status and phytochelatin biosynthesis. Plant Physiol. Biochem. 2012, 57, 15-22. [CrossRef]

27. Borges, K.L.R.; Salvato, F.; Alcântara, B.K.; Nalin, R.S.; Piotto, F.Â.; Azevedo, R.A. Temporal dynamic responses of roots in contrasting tomato genotypes to cadmium tolerance. Ecotoxicology 2018, 27, 245-258. [CrossRef] 
28. Cai, K.; Li, C.; Song, Z.; Gao, X.; Wu, M. Pollution and health risk assessment of carcinogenic elements As, Cd, and Cr in multiple media-A case of a sustainable farming area in China. Sustainability 2019, 11, 5208. [CrossRef]

29. Ismael, M.A.; Elyamine, A.M.; Moussa, M.G.; Cai, M.; Zhao, X.; Hu, C. Cadmium in plants: Uptake, toxicity, and its interactions with selenium fertilizers. Metallomics 2019, 11, 255-277. [CrossRef]

30. Singh, O.V.; Labana, S.; Pandey, G.; Budhiraja, R.; Jain, R.K. Phytoremediation: An overview of metallic ion decontamination from soil. Appl. Microbiol. Biotechnol. 2003, 61, 405-412. [CrossRef] [PubMed]

31. Nirola, R.; Megharaj, M.; Palanisami, T.; Aryal, R.; Venkateswarlu, K.; Naidu, R. Evaluation of metal uptake factors of native trees colonizing an abandoned copper mine-A quest for phytostabilization. J. Sustain. Min. 2015, 14, 115-123. [CrossRef]

32. Desjardins, D.; Pitre, F.E.; Nissim, W.G.; Labrecque, M. Differential uptake of silver, copper and zinc suggests complementary species-specific phytoextraction potential. Int. J. Phytoremediat. 2016, 18, 598-604. [CrossRef] [PubMed]

33. Siddique, A.B.; Rahman, M.M.; Islam, M.R.; Mondal, D.; Naidu, R. Response of Iron and Cadmium on Yield and Yield Components of Rice and Translocation in Grain: Health Risk Estimation. Front. Environ. Sci. 2021, 9, 716770. [CrossRef]

34. Seo, B.-H.; Kim, H.S.; Kuppusamy, S.; Kim, K.-H.; Kim, K.-R. Enhanced nitrogen and phosphorus removal by woody plants with deep-planting technique for the potential environmental management of carcass burial sites. Sustainability 2017, 9, 155. [CrossRef]

35. Abbasi, H.; Pourmajidian, M.R.; Hodjati, S.M.; Fallah, A.; Nath, S. Effect of soil-applied lead on mineral contents and biomass in Acer cappadocicum, Fraxinus excelsior and Platycladus orientalis seedlings. iForest 2017, 10, 722-728. [CrossRef]

36. Li, S.S.; Wang, M.; Zhao, Z.Q.; Ma, C.B.; Chen, S.B. Adsorption and desorption of Cd by soil amendment: Mechanisms and environmental implications in field-soil remediation. Sustainability 2018, 10, 2337. [CrossRef]

37. Gerhardt, K.; Gerwing, P.; Greenberg, B. Opinion: Taking phytoremediation from proven technology to accepted practice Plant Sci. 2017, 256, 170-185. [CrossRef]

38. Hussain, S.; Akram, M.; Abbas, G.; Murtaza, B.; Shahid, M.; Shah, N.S.; Bibi, I.; Niazi, N.K. Arsenic tolerance and phytoremediation potential of Conocarpus erectus L. and Populus deltoides L. Int. J. Phytoremediat. 2017, 19, 985-991. [CrossRef]

39. Liu, Y.; Yang, Y.; Li, C.; Ni, X.; Ma, W.; Wei, H. Assessing soil metal levels in an industrial environment of northwest china and the phytoremediation potential of its native plants. Sustainability 2018, 10, 2686. [CrossRef]

40. Whiting, S.N.; Leake, J.R.; McGrath, S.P.; Baker, A.J. Positive responses to Zn and Cd by roots of the Zn and Cd hyperac-cumulator Thlaspi caerulescens. New Phytol. 2000, 145, 199-210. [CrossRef]

41. McGrath, S.P.; Lombi, E.; Gray, C.W.; Caille, N.; Dunham, S.J.; Zhao, F.J. Field evaluation of Cd and Zn phytoextraction potential by the hyperaccumulators Thlaspi caerulescens and Arabidopsis halleri. Environ. Pollut. 2006, 141, 115-125. [CrossRef] [PubMed]

42. Sun, Y.B.; Zhou, Q.X.; Wang, L.; Liu, W.T. Cadmium tolerance and accumulation characteristics of Bidens pilosa L. as a potential Cd-hyperaccumulator. J. Hazard. Mater. 2008, 161, 808-814. [CrossRef]

43. Jaffré, T.; Pillon, Y.; Thomine, S.; Merlot, S. The metal hyperaccumulators from new caledonia can broaden our understanding of nickel accumulation in plants. Front. Plant Sci. 2013, 4, 279. [CrossRef]

44. Shah, V.; Daverey, A. Phytoremediation: A multidisciplinary approach to clean up heavy metal contaminated soil. Environ. Technol. Innov. 2020, 18, 100774. [CrossRef]

45. Roosens, N.; Verbruggen, N.; Meerts, P.; Ximenez-Embun, P.; Smith, J. Natural variation in cadmium tolerance and its relationship to metal hyperaccumulation for seven populations of Thlaspi caerulescens from western Europe. Plant Cell Environ. 2003, 10, 1657-1672. [CrossRef]

46. Krämer, U. Metal hyperaccumulation in plants. Annu. Rev. Plant Biol. 2010, 61, 517-534. [CrossRef]

47. Ent, A.V.D.; Baker, A.J.M.; Reeves, R.D.; Pollard, A.J.; Schat, H. Hyperaccumulators of metal and metalloid trace elements: Facts and fiction. Plant Soil 2013, 362, 319-334.

48. Forte, J.; Mutiti, S. Phytoremediation potential of Helianthus annuus and Hydrangea paniculata in copper and lead-contaminated soil. Water Air Soil Pollut. 2017, 228, 77. [CrossRef]

49. Yadav, K.K.; Gupta, N.; Kumar, A.; Reece, L.M.; Singh, N.; Rezania, S.; Khan, S.A. Mechanistic understanding and holistic approach of phytoremediation: A review on application and future prospects. Ecol. Eng. 2018, 120, 274-298. [CrossRef]

50. Navarro-León, E.; Oviedo-Silva, J.; Ruiz, J.M.; Blasco, B. Possible role of HMA4a TILLING mutants of Brassica rapa in cadmium phytoremediation programs. Ecotoxicol. Environ. Saf. 2019, 180, 88-94. [CrossRef]

51. Coakley, S.; Cahill, G.; Enright, A.-M.; O’Rourke, B.; Petti, C. Cadmium Hyperaccumulation and Translocation in Impatiens Glandulifera: From Foe to Friend? Sustainability 2019, 11, 5018. [CrossRef]

52. Dai, H.; Wei, S.; Skuza, L.; Zhang, Q. Phytoremediation of two ecotypes cadmium hyperaccumulator Bidens pilosa L. sourced from clean soils. Chemosphere 2021, 273, 129652. [CrossRef] [PubMed]

53. Huang, R.; Dong, M.; Mao, P.; Zhuang, P.; Paz-Ferreiro, J.; Li, Y.; Li, Y.; Hu, X.; Netherway, P.; Li, Z. Evaluation of phytoremediation potential of five $\mathrm{Cd}$ (hyper) accumulators in two Cd contaminated soils. Sci. Total Environ. 2020, 721, 137581. [CrossRef]

54. Antoniadis, V.; Shaheen, S.M.; Stärk, H.J.; Wennrich, R.; Levizou, E.; Merbach, I.; Rinklebe, J. Phytoremediation potential of twelve wild plant species for toxic elements in a contaminated soil. Environ. Int. 2021, 146, 106233. [CrossRef]

55. Wilson, A.; Kendal, D.; Moore, J.L. Humans and ornamental plants: A mutualism? Ecopsychology 2016, 8, 257-263. [CrossRef]

56. Scholz, T.; Hof, A.; Schmitt, T. Cooling effects and regulating ecosystem services provided by urban trees novel analysis approaches using urban tree cadastre data. Sustainability 2018, 10, 712. [CrossRef]

57. Ciftcioglu, G.C.; Ebedi, S.; Abak, K. Evaluation of the relationship between ornamental plants-based ecosystem services and human wellbeing: A case study from Lefke Region of North Cyprus. Ecol. Indic. 2019, 102, 278-288. [CrossRef] 
58. Zhang, Z.; Liu, Y.; Hu, S.; Wang, J.; Qian, J. A new type of ecological floating bed based on ornamental plants experimented in an artificially made eutrophic water body in the laboratory for nutrient removal. Bull. Environ. Contam. Toxicol. 2021, 106, 2-9. [CrossRef] [PubMed]

59. Cheng, L.; Wang, Y.; Cai, Z.; Liu, J.; Yu, B.; Zhou, Q. Phytoremediation of petroleum hydrocarbon-contaminated saline-alkali soil by wild ornamental Iridaceae species. Int. J. Phytoremediat. 2017, 19, 300-308. [CrossRef]

60. Chandanshive, V.V.; Kadam, S.K.; Khandare, R.V.; Kurade, M.B.; Jeon, B.H.; Jadhav, J.P.; Govindwar, S.P. In situ phytoremediation of dyes from textile wastewater using garden ornamental plants, effect on soil quality and plant growth. Chemosphere 2018, 210, 968-976. [CrossRef]

61. Mukherjee, A.; Agrawal, M. Use of GLM approach to assess the responses of tropical trees to urban air pollution in relation to leaf functional traits and tree characteristics. Ecotoxicol. Environ. Saf. 2018, 152, 42-54. [CrossRef] [PubMed]

62. Teiri, H.; Pourzamani, H.; Hajizadeh, Y. Phytoremediation of VOCs from indoor air by ornamental potted plants: A pilot study using a palm species, under the controlled environment. Chemosphere 2018, 197, 375-381. [CrossRef] [PubMed]

63. Manzoor, M.; Gul, I.; Ahmed, I.; Zeeshan, M.; Hashmi, I.; Amin, B.A.Z.; Kallerhoff, J.; Arshad, M. Metal tolerant bacteria enhanced phytoextraction of lead by two accumulator ornamental species. Chemosphere 2019, 227, 561-569. [CrossRef] [PubMed]

64. Kotsia, D.; Deligianni, A.; Fyllas, N.M.; Stasinakis, A.S.; Fountoulakis, M.S. Converting treatment wetlands into "treatment gardens": Use of ornamental plants for greywater treatment. Sci. Total Environ. 2020, 744, 140889. [CrossRef] [PubMed]

65. Rydlová, J.; Püschel, D. Arbuscular mycorrhiza, but not hydrogel, alleviates drought stress of ornamental plants in peat-based substrate. Appl. Soil Ecol. 2020, 146, 103394. [CrossRef]

66. Saxena, P.; Sonwani, S. Remediation of ozone pollution by ornamental plants in indoor environment. Glob. J. Environ. Sci. Manag. 2020, 6, 497-508.

67. Gladkov, E.A.; Gladkova, O.V. Ornamental plants adapted to urban ecosystem pollution: Lawn grasses tolerating deicing reagents. Environ. Sci. Pollut. Res. 2021. [CrossRef]

68. Taemthong, W. Air quality improvement using ornamental plants in classrooms. J. Green Build. 2021, 16, 201-216. [CrossRef]

69. Traversari, S.; Cacini, S.; Galieni, A.; Nesi, B.; Nicastro, N.; Pane, C. Precision Agriculture Digital Technologies for Sustainable Fungal Disease Management of Ornamental Plants. Sustainability 2021, 13, 3707. [CrossRef]

70. Lu, R.K. Analytical Methods for Soils and Agricultural Chemistry; China Agricultural Science and Technology Press: Beijing, China, 1999. (In Chinese)

71. Liu, A.; Hamel, C.; Elmi, A.; Costa, C.; Ma, B.; Smith, D.L. Concentrations of K, Ca and Mg in maize colonized by arbuscular mycorrhizal fungi under field conditions. Can. J. Soil Sci. 2002, 82, 271-278. [CrossRef]

72. Javed, M.T.; Akram, M.S.; Tanwir, K.; Chaudhary, H.J.; Ali, Q.; Stoltz, E.; Lindberg, S. Cadmium spiked soil modulates root organic acids exudation and ionic contents of two differentially Cd tolerant maize (Zea mays L.) cultivars. Ecotoxicol. Environ. Saf. 2017, 141, 216-225. [CrossRef] [PubMed]

73. Calabrese, E.J.; Baldwin, L.A. Toxicology rethinks its central belief: Hormesis demands a reappraisal of the way risks are assessed. Nature 2003, 421, 691-692. [CrossRef] [PubMed]

74. Calabrese, E.J. Hormesis: Why it is important to toxicology and toxicologists. Environ. Toxicol. Chem. 2008, 27, 1451-1474. [CrossRef] [PubMed]

75. Calabrese, E.J.; Blain, R.B. Hormesis and plant biology. Environ. Pollut. 2009, 157, 42-48. [CrossRef]

76. Liu, Z.; Chen, W.; He, X.; Jia, L.; Yu, S.; Zhao, M. Hormetic responses of Lonicera Japonica Thunb. to cadmium stress. Dose-Response 2015, 13, 1-10. [CrossRef] [PubMed]

77. Bayçu, G.; Moustaka, J.; Gevrek, N.; Moustakas, M. Chlorophyll fluorescence imaging analysis for elucidating the mechanism of photosystem II acclimation to cadmium exposure in the hyperaccumulating plant Noccaea caerulescens. Materials 2018, 11, 2580. [CrossRef]

78. Zeng, P.; Guo, G.; Xiao, X.; Peng, C.; Feng, W. Phytoextraction potential of Pteris vittata L. co-planted with woody species for As, $\mathrm{Cd}, \mathrm{Pb}$ and $\mathrm{Zn}$ in contaminated soil. Sci. Total Environ. 2019, 650, 594-603. [CrossRef]

79. Martin, R.J.; Deo, B. Effect of plant population on calendula (Calendula officinalis L.) flower production. N. Z. J. Crop Hort. Sci. 2000, 28, 37-44. [CrossRef]

80. Gesch, R.W. Growth and yield response of calendula (Calendula officinalis) to sowing date in the northern U.S. Ind. Crop Prod. 2013, 45, 248-252. [CrossRef]

81. Król, B.; Paszko, T. Harvest date as a factor affecting crop yield, oil content and fatty acid composition of the seeds of calendula (Calendula officinalis L.) cultivars. Ind. Crop Prod. 2017, 97, 242-251. [CrossRef]

82. Biermann, U.; Butte, W.; Holtgrefe, R.; Feder, W.; Metzger, J.O. Esters of calendula oil and tung oil as reactive diluents for alkyd resins. Eur. J. Lipid Sci. Technol. 2010, 112, 103-109. [CrossRef] 